\title{
PENGEMBANGAN BUKU AJAR BAHASA INDONESIA DENGAN MODEL CIRC UNTUK MENINGKATKAN KETERAMPILAN LITERASI BERBAHASA SISWA KELAS V SD
}

\author{
${ }^{1}$ Finna Rahma Hijria, ${ }^{2}$ Bambang Yulianto, ${ }^{3}$ Setya Yuwana \\ ${ }^{1}$ Mahasiswa Program Pascasarjana, Prodi Pendidikan Dasar, Universitas Negeri Surabaya, \\ ${ }^{2 \& 3}$ Dosen Pascasarjana, Prodi Pendidikan Dasar, Universitas Negeri Surabaya \\ e-mail: finnarahma20@gmail.com
}

Received : November 2017

Reviewed : Desember 2017

Accepted : Januari 2018

Published : Januari 2018
ABSTRACT

The purpose of this study is to develop a Indonesian textbook CIRC model to improve language literacy skills of $5^{\text {th }}$ grade elementary students. The specific objectives of this study are (1) to describe the process of developing Indonesian textbooks with CIRC model to improve students' language literacy skills of elementary school classrooms, (2) to describe the quality of Indonesian texsbooks with CIRC model. Quality developed textbooks is reviewed based on products and their use in the classroom. This development study referred to the four-D development model which consists of four stages (1) define; (2) design; (3) develop, and (4) disseminate. However, this research was only limited at the development stage without doing dissemination because this research product was for trial school in particular. The data collection used documentation technique, observation, questionnaire, and test. The obtained data was analysed by qualitative-quantitative descriptive (mixed method). The results from this research 90,62\% of material feasibility, 92,5\% of presentation feasibility, $100 \%$ language feasibility, and $86,36 \%$ feasibility was gotten from the research results. All of those percentagesbelonged to the good quality category (proper). The results from the observation toward teacher and students, activity were $89,2 \%$ and 92,04\%. The teacher and students' responses toward CIRC model in Bahasa Indonesia textbook were $87,5 \%$ and $83,33 \%$. The students' average test score was 82,63 meet a students' standard competence of 75 .

Keywords: Textbook Elaboration, Language Literacy, CIRC Model.

\section{ABSTRAK}

Tujuan umum penelitian ini adalah mengembangkan buku ajar Bahasa Indonesia dengan model CIRC untuk meningkatkan keterampilan Literasi berbahasa siswa kelas V SD. Adapun tujuan khusus penelitian ini adalah (1) mendeskripsikan proses pengembangan buku ajar Bahasa Indonesia dengan model CIRC untuk meningkatkan keterampilan literasi berbahasa siswa kelass $V$ SD, (2) mendeskripsikan kualitas buku ajar Bahasa Indonesia dengan model CIRC. Kualitas buku ajar yang dikembangkan ditinjau berdasarkan produk dan penggunaannya di kelas. Penelitian pengembangan ini mengacu pada model pengembangan four-D yang terdiri atas tahap (1) pendefinisian; (2) perancangan; (3) pengembangan; dan (4) penyebaran. Akan tetapi, penelitian ini hanya sampai pada tahap pengembangan tanpa melakukan penyebaran karena produk penelitian ini hanya dikhususkan sekolah uji coba. Pengumpulan data dilakukan menggunakan teknik dokumentasi, observasi, angket, dan tes. Data yang diperoleh dianalisis secara deskriptif kualitatif-kuantitatif. Berdasarkan hasil penelitian diperoleh hasil persentase kelayakan materi 90,62\%, kelayakan penyajian 92,5\%, kelayakan kebahasaan $100 \%$, dan kelayakan kegrafikaan 86,36\%. Semua kategori tersebut termasuk kategori berkualitas (sangat layak/baik). Perolehan hasil observasi terhadap aktivitas guru dan siswa berturut-turut adalah 89,2\% dan 92,04\%. Respon guru dan siswa terhadap buku ajar Bahasa Indonesia model CIRC adalah 87,5\% dan 83,33\%. Rata-rata hasil belajar siswa sebesar 82,63 yang sesuai dengan kriteria ketuntasan yaitu 75. 
Kata Kunci: Pengembangan Buku Ajar, Literasi Berbahasa, Model Pembelajaran CIRC.

\section{PENDAHULUAN}

Kemampuan berbahasa Indonesia, termasuk keterampilan literasi perlu mendapatkan penekanan dalam kompetensi, pemilihan materi dan distribusinya di SD dan sekolah menengah. SD menjadi dasar pembelajaran literasi karena SD merupakan awal seorang anak belajar membaca dan menulis. Melalui pendidikan SD, siswa diharapkan memperoleh bekal kemampuan literasi, yakni membaca dan menulis.

Tingkat literasi membaca siswa di seluruh dunia dapat diketahui dari tiga studi Internasional yang dipercaya sebagai instrumen untuk menguji kompetensi global, yaitu PISA, PIRLS, dan TIMSS. Hasil penelitian Programme for International Student Assessment (PISA) menyebut, budaya literasi masyarakat Indonesia pada 2012 terburuk kedua dari 65 negara yang diteliti di dunia. Indonesia menempati urutan ke 64 dari 65 negara tersebut.

Berdasarkan hasil penelitian di atas dapat diketahui bahwa tingkat literasi bangsa Indonesia sangat rendah. Seperti halnya di sekolah dasar, kurikulum baru yang diterapkan pada sekolah adalah kurikulum 2013 atau yang disebut dengan K13. Materi pada K13 sudah terstruktur. Materi sudah tersusun rapi setiap harinya, namun guru masih perlu untuk memahami dan mempelajari K13. Berkaitan dengan materi yang setiap hari sudah tersusun dan harus dilaksanakan sesuai targetnya, guru seakan-akan tak memperdulikan apakah materi yang disampaikan sudah dipahami oleh siswa apa belum. Dengan demikian, banyak siswa sekolah dasar yang kurang memahami tentang materi yang telah diberikan oleh gurunya.

Di sisi lain, belum tersedia buku ajar membaca dan menulis yang dikembangkan berdasarkan pendekatan atau metode pembelajaran tertentu yang ditujukan untuk meningkatkan keterampilan literasi berbahasa. Buku pelajaran berisi unit-unit materi pembelajaran yang harus diikuti oleh peserta didik melalui serangkaian kegiatan dan pelatihan seperti membaca teks, menganalisis teks, mendiskusikan isi teks, merefleksi, dan lain-lain. Ada guru yang mengambil materi ajar dari buku pelajaran, tetapi ada juga guru yang menggunakan buku pelajaran secara selektif, dalam arti ia hanya memilih materi dari buku pelajaran yang diperlukan sesuai dengan kebutuhan dan kurikulum yang berlaku.

Dengan pernyataan di atas, peneliti tertarik untuk mengembangkan buku ajar Bahasa Indonesia yang ditujukan untuk meningkatkan keterampilan literasi berbahasa siswa. Sesuai dengan observasi dan wawancara yang telah dilaksanakan di SD Hang Tuah 6 Surabaya, siswa kelas $\mathrm{V}$ masih kesulitan dalam memahami materi pembelajaran menulis dan memahami bacaan. Ketika siswa disuruh untuk merangkum suatu bacaan, mereka cenderung mengerjakan asal-asalan tanpa memperhatikan ide pokok, tanda baca, ataupun keruntutan kalimat. Bahkan ketika siswa disuruh untuk membuat suatu paragraf, bahasa yang digunakan tidak menggunakan bahasa yang benar, mereka menulis menggunakan bahasa tidak baku. Padahal mayoritas siswa menggunakan bahasa Indonesia dalam kehidupan sehari-hari.

Dengan mengembangkan buku ajar Bahasa Indonesia diharapkan kesulitan siswa dalam keterampilan literasi berbahasa dapat teratasi sehingga kemampuan berliterasi siswa diharapkan meningkat. Buku ajar yang dikembangkan dalam penelitian ini adalah buku ajar Bahasa Indonesia dengan model CIRC. Pengembangan buku ajar Bahasa Indonesia dengan model CIRC diharapkan dapat menarik minat siswa, memperkuat daya kreatif siswa saat pembelajaran, menciptakan pembelajaran yang inovatif, melatih membentuk siswa untuk berani menyampaikan gagasan, berani berkreasi, mengembangkan gagasan dalam bentuk cerita dan lain-lain. Artinya buku ajar dalam pembelajaran ini nantinya diharapkan dapat memancing keterampilan berliterasi siswa.

Pengembangan buku ajar ini menggunakan model (Cooperative Integrated Reading and Composition) CIRC karena model pembelajaran CIRC ini, sangat cocok digunakan dalam pembelajaran Bahasa Indonesia. Model pembelajaran kooperatif tipe Cooperative Integrated Reading and Composition (CIRC) merupakan model pembelajaran yang tepat digunakan untuk meningkatkan keterampilan literasi berbahasa siswa. Model pembelajaran kooperatif tipe CIRC dari segi bahasa dapat diartikan sebagai suatu model pembelajaran kooperatif yang mengintegrasikan suatu bacaan secara menyeluruh kemudian mengkomposisikannya menjadi bagian-bagian yang penting. Menurut Slavin (2005:200) CIRC adalah sebuah program komprehensif atau luas dan lengkap untuk pembelajaran membaca dan menulis untuk kelas-kelas tinggi sekolah dasar. CIRC merupakan salah satu model pembelajaran kooperatif yang mengutamakan kerjasama dalam kelompok untuk membantu siswa belajar memahami materi pelajaran melalui bacaan, berita, dan permasalahan.

Berdasarkan paparan tersebut, maka peneliti termotivasi untuk meneliti dan mengembangkan penelitian 
dengan judul "Pengembangan Buku Ajar Bahasa Indonesia dengan Model CIRC untuk Meningkatkan Keterampilan Literasi Berbahasa Siswa Kelas V Sekolah Dasar"

\section{TINJAUAN PUSTAKA}

Buku ajar adalah sumber belajar berbentuk bahan ajar yang dipergunakan oleh siswa untuk membantu tercapainya standar kompetensi, kompetensi dasar dan tujuan pendidikan yang telah ditetapkan. Sedangkan bahan ajar itu sendiri merupakan seperangkat materi yang disusun secara sistematis sehingga tercipta lingkungan atau suasana memungkinkan siswa untuk belajar (Depdiknas, 2006) .

Fungsi atau kegunaan buku ajar antara lain adalah (a) pedoman pembelajaran dan pebelajar dalam suatu proses pembelajaran, (b) menyajikan suatu sumber belajar yang tersusun rapi dan dapat menarik minat atau motivasi pebelajar, (c) menyajikan bahan sarana evaluasi terhadap penguasaan materi atau bahan ajar.

Pada penelitian ini, buku ajar bahasa Indonesia kelas $\mathrm{V}$ semester genap yang berkualitas adalah buku ajar yang memiliki empat unsur ketepatan dalam komponen penyusunan buku menurut Muslich (2010: 303). Keempat komponen itu seperti, ketepatan materi, ketepatan penyajian, ketepatan penyajian, ketepatan kebahasaan, dan ketepatan kegrafikaan.

Model pembelajaran kooperatif tipe CIRC merupakan singkatan dari Cooperative Integrated Reading and Composition, termasuk salah satu model pembelajaran cooperative learning yang pada mulanya merupakan pengajaran kooperatif terpadu membaca dan menulis yaitu sebuah program komprehensif atau luas dan lengkap untuk pengejaran membaca dan menulis untuk kelas-kelas tinggi sekolah dasar. Menurut Kurniasih (2015:89-90) model pembelajaran Cooperative Integrated Reading and Composition - CIRC (Kooperatif membaca dan menulis) merupakan model pembelajaran yang lebih cocok dan tepat diaplikasikan pada mata pelajaran Bahasa Indonesia khusus pada materi membaca, menemukan ide pokok, pokok pikiran atau tema sebuah wacana atau kliping.

Tujuan utama dari para pengembang CIRC terhadap pelajaran menulis dan seni berbahasa adalah untuk merancang, mengimplementasikan, dan mengevaluasi pendekatan proses menulis pada pelajaran menulis dan seni berbahasa yang akan banyak memanfaatkan kehadiran teman satu kelas. Respon dari kelompok teman adalah unsur khas dari model-model proses penulisan, tetapi keterlibatan teman jarang sekali menjadi kegiatan sentralnya. Dalam program CIRC para siswa merencanakan, merevisi, dan menyunting karangan mereka dengan kolaborasi yang erat dengan teman satu tim mereka. Pengajaran mekanika bahasa benar-benar terintregasi sekaligus menjadi bagian dari pelajaran menulis dan membaca. Pelajaran menulis terintregasi dengan pengajaran pelajaran memahami bacaan baik dengan keterpaduan kegiatan-kegiatan proses menulis dalam program membaca maupun dengan penggunaan kemampuan memahami bacaan yang baru dipelajari.

Literasi merupakan pendekatan pembelajaran bahasa yang relevan untuk pendidikan bahasa yang berorientasi pada kecakapan hidup yang pada gilirannya dapat berkomunikasi. Sebagaimana dikemukakan Hammond (dalam Sodiq, 2010:88) bahwa pendekatan literasi merupakan pendekatan pendidikan bahasa yang menyiapkan siswanya untuk dapat berpartisipasi dalam kehidupan masyarakat modern.

Tomkins (1991:18) mengemukakan bahwa literasi merupakan kemampuan menggunkan membaca dan menulis dalam melaksanakan tugas yang bertalian dengan dunia kerja dan kehidupan di luar sekolah. Selanjutnya dikatakan bahwa literasi merupakan kemampuan bergaul dengan wacana sebagai representasi pengalaman, pikiran, perasaan, dan gagasan secara tepat sesuai dengan tujuan.

Keterampilan literasi berbahasa siswa yang ditingkatkan dalam penelitian ini adalah keterampilan literasi membaca dan menulis. Peneliti meningkatkan keterampilan literasi membaca dan menulis karena siswa sekolah dasar pada umumnya kurang dalam memahami keterampilan membaca dan menulis. Kurangnya kemampuan membaca dan menulis siswa, dibuktikan dengan penelitian yang dilakukan oleh PISA, kemampuan membaca dan menulis siswa di Indonesia berada pada urutan ke 57 dari 65 negara yang diteliti. Oleh sebab itu, peneliti ingin meningkatkan keterampilan literasi membaca dan menulis. Bentuk-bentuk penilaian dalam memberikan nilai siswa dapat dijabarkan sebagai berikut.

Tabel 1 Bentuk Penilaian

\begin{tabular}{|c|c|c|}
\hline No & Aspek & Subaspek \\
\hline \multirow[t]{3}{*}{1} & Membaca & 1. Ide pokok \\
\hline & & $\begin{array}{l}\text { 2. Menjawab } \\
\text { pertanyaan sesuai } \\
\text { dengan isi cerita }\end{array}$ \\
\hline & & $\begin{array}{l}\text { 3. Menyimpulkan isi } \\
\text { bacaan }\end{array}$ \\
\hline \multirow[t]{4}{*}{2.} & Menulis & a. Isi \\
\hline & & b. Bentuk kalimat \\
\hline & & c. Tata bahasa \\
\hline & & $\begin{array}{l}\text { d. Kesesuaian tanda } \\
\text { baca }\end{array}$ \\
\hline
\end{tabular}




\section{METODE}

Ditinjau dari aspek tujuan, penelitian ini merupakan penelitian pengembangan. Dalam penelitian ini dilakukan pengembangan buku ajar Bahasa Indonesia dengan model CIRC di kelas V sekolah dasar. Buku ajar hasil pengembangan ini akan duji cobakan dan hasil uji coba ini akan dianalisis secara deskriptif kualitatif untuk menjawab rumusan masalah sedangkan data kuantitatif untuk melihat nilai atau persentase data kualitas produk buku.Tahap pendefinisian bertujuan untuk menetapkan dan mendefinisikan syarat-syarat pembuatan buku teks. Ada lima langkah pokok dalam tahap pendefinisian. Tahap tersebut yaitu analisis awal akhir, analisis siswa, analisis konsep, analisis tugas, dan analisis tujuan pembelajaran. Model pengembangan dalam penelitian ini mengacu pada teori Four D Model. Menurut Thiagarajan, Semmel dan Semmel (1947:3) model pengembangan ini terdiri atas empat tahap pengembangan yaitu define, design, develop, dan dessiminate atau diadaptasi menjadi model 4-P, yaitu Pendefinisian, Perancangan, Pengembangan dan Penyebaran. Dalam penelitian ini pengembangan buku ajar disederhanakan hanya sampai pada tahap develop tanpa tahap dessiminate, sehingga buku ajar yang telah dikembangkan hanya digunakan pada sekolah uji coba saja, tanpa disebarkan pada sekolah lain.

Perencanaan penulisannya sesuai dengan syarat dari BSNP (2007) yaitu memperhatikan kelayakan isi, kelayakan penyajian, kelayakan kebahasaan, dan kelayakan kegrafikaan. Buku ajar yang telah disusun mengalami penyuntingan. Perubahan pada penulisan dan penyusunan telah dilakukan saat ada kekurangan dan penambahan. Buku ajar yang telah dihasilkan merupakan draf I buku ajar pelajaran bahasa Indonesia dengan model CIRC. Proses selanjutnya adalah validasi buku ajar draf I, pada validator adalah orang yang ahli di bidang materi dan pembelajaran, ahli bidang kebahasaan dan ahli bidang kegrafikaan.

Penilaian masukan dan saran validator I digunakan untuk merevisi draf I buku ajar. Berdasarkan masukan dari validator draf awal buku ajar hasil pengembangan direvisi. Hasil revisi ini disebut dengan draf II. Sebelum uji coba terbatas draf II dilakukan, peneliti menyiapkan silabus dan RPP menggunakan model CIRC. Kegiatan dilanjutkan dengan uji terbatas draf II (buku ajar bahasa Indonesia dengan model CIRC untuk meningkatkan keterampilan literasi berbahasa siswa kelas V). Kegiatan penelitian selanjutnya adalah implementasi dari buku ajar tersebut, yaitu aktivitas siswa saat menggunakan buku ajar tersebut dan hasil belajar siswa setelah menggunakan buku ajar tersebut. Kegiatan ini diakhiri dengan analisis deskriptif kualitatif untuk menjawab rumusan-rumusan masalah pada bab pertama.

Data penelitian ini berasal dari proses pengembangan buku ajar bahasa Indonesia dengan model CIRC dan kualitas pengembangan buku ajar bahasa Indonesia dengan model CIRC menurut validator dan uji coba produk. Adapun data yang dihasilkan sebagai berikut. a) data proses pengembangan merupakan data dari hasil tahap pendefinisian (define) dan tahap perancangan (design). Data hasil tahap pendefinisian yaitu berupa rumusan KI dan KD. Data hasil tahap perancangan berupa penilaian dari tim validator untuk draf I buku ajar. b) data kualitas buku ajar dari hasil tahap pengembangan (develop) yaitu skor nilai dari validator dan calon pengguna. Seacara rinci hal itu dapat dijelaskan sebagai berikut. 1) skor nilai hasil validasi draf II buku ajar untuk kelayakan materi, bahasa, penyajian dan kegrafikaan digunakan sebagai data untuk menjawab masalah kualitas buku ajar dari segi produk. 2) skor nilai dari data analisis guru, analisis siswa dan hasil belajar siswa baik dari uji coba terbatas maupun uji coba luas sebagai data untuk kualitas buku ajar dari segi penggunaan.

Sumber data dari penilaian kualitas buku ajar terdiri dari 24 responden. Rincian responden tersebut sebagai berikut. (1) sumber data dari proses pengembangan (develop) yaitu standar isi pada kurikulum 2013. (2) Sumber data dari penilaian kualitas buku ajar terdiri dari 24 responden.

Teknik analisis data untuk menjawab rumusan masalah pertama yaitu tentang proses pengembangan buku ajar bahasa Indonesia ini diambil dengan teknik dokumentasi terhadap keterampilan literasi serta pemetaan KI dan KD. Data yang diolah berupa KI dan KD yang berasal dari standar isi kurikulum 2013. Teknik

Pengumpulan data untuk menjawab rumusan masalah yang kedua yaitu tentang kualitas buku ajar dari penilaian validator dan dari segi penggunaannya menggunakan teknik validasi, observasi, angket dan tes.

Sedangkan teknik penganalisisan analisis data dalam penelitian ini dilakukan secara deskriptif dan statistik deskriptif. Analisis deskriptif berfungsi memberikan, memaparkan atau menyajikan informasi. Sebagaimana pendapat Arikunto (2009:268), menyatakan bahwa penelitian yang menggunakan analisisis deskriptif kualitatif adalah penelitian evaluasi yang bertujuan untuk menilai sejauh mana variabel yang diteliti telah sesuai dengan tolak ukur yang sudah ditentukan. Sedangkan dengan statistik deskriptif kumpulan data yang diperoleh akan tersaji dengan ringkas dan rapi serta dapat memberikan informasi inti dari kumpulan data yang ada. 
Dalam penelitian ini, analisis yang dilakukan terhadap proses pengembangan buku ajar, kualitas buku ajar, dan pengimplementasian buku ajar tersebut dalam proses mengajar. Dalam penelitian ini, analisis yang dilakukan terhadap proses pengembangan buku ajar, kualitas buku ajar, dan pengimplementasian buku ajar tersebut dalam proses belajar mengajar. Analisis akan dijelaskan sebagai berikut. (a) pada tahap pendefinisian dan perancangan. Analisis data untuk menjawab rumusan masalah pertama proses pengembangan buku ajar bahasa Indonesia ini menggunakan teknik analisis deskriptif kualitatif. (b) pada tahap pengembangan Analisis data untuk menjawab rumusan masalah yang kedua kualitas produk buku ajar yang dikembangkan dengan model CIRC dilakukan melaluli teknik analisis deskriptif kuantitatif dari hasil observasi terhadap aktivitas, respon guru dan siswa, serta hasil belajar siswa selama penggunaan draf II buku ajar.

Kualitas penggunaan buku dilihat dari produknya

$$
\mathrm{P}(\%)=\frac{\text { Skor yang diperoleh }}{\text { Skor maksimal }} \times 100 \%
$$

(Arikunto, 2006:40)

Buku ajar dianggap layak untuk digunakan apabila interpretasinya $\geq 60$.

Standar penilaian kelayakan buku ajar sebagai berikut:

Tabel 2 Standar Penilaian

\begin{tabular}{ll}
\hline Skor & Kriteria \\
$81 \%-100 \%$ & Sangat Layak \\
$61 \%-80 \%$ & Layak \\
$41 \%-60 \%$ & Cukup Layak \\
$21 \%-40 \%$ & Kurang Layak \\
$0 \%-20 \%$ & Tidak Layak \\
\hline
\end{tabular}

Observasi untuk mengetahui persentase perolehan aktivitas guru dan siswa menggunakan rumus

$$
\mathrm{P}(\%)=\quad \mathrm{X} 100 \%
$$

Keterangan

$\mathrm{P} \quad=$ Persentase keterlaksanaan pembelajaran

$\Sigma K=$ Frekuensi aspek yang dilakukan

$\sum N=$ Frekuensi keseluruhan komponen yang diamati

(Arikunto,2010: 18)

Persentase data angket guru setelah menggunakan buku ajar yang diperoleh dan dihitung berdasarkan rumus rating scale berikut:

$$
\mathrm{P}(\%)=\quad \mathrm{X} 100 \%
$$

(Riduwan, 2005: 21)

Keterangan

Skor kriterium $=$ skor tertinggi $\mathrm{x}$ jumlah item dari pernyataan $\mathrm{x}$ jumlah responden

Rumus hasil belajar siswa dilakukan dengan menghitung untuk mengetahui perbedaan pre-test dan post-tes.

$$
\text { Nilai }=\frac{\text { skor perolehan }}{\text { skor maksimal }} \times 100
$$

Siswa dinyatakan tuntas belajar apabila mencapai nilai $\mathrm{KKM} \geq 75$. Selanjutnya, dilakukan analisis hasil belajar siswa setelah menggunakan produk buku. Untuk mengetahui peningkatan hasil belajar siswa digunakan perhitungan dengan rumus.

Rumus peningkatan hasil belajar siswa digunakan perhitungan

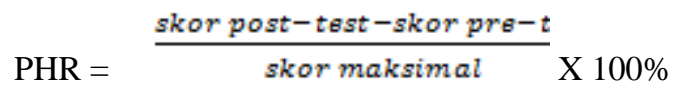

Pembelajarn secara klasikal dikatakan tuntas apabila $\geq$ 75\% individu tuntas. Untuk menghitung ketuntasan belajar secara klasikal (PK) dihitung dengan menggunakan rumus.

\section{jumlah siswa yang to \\ P. Klasikal $=\quad$ jumlah seluruh sis $\mathrm{X} 100$}

(Arikunto, 2006:306-307)

\section{HASIL DAN PEMBAHASAN}

Pengembangan perangkat yang dilakukan peneliti mengikuti langkah-langkah model pengembangan Thiagarajan, Semmel dan Semmel (model 4-D) dengan langkah-langkah yang telah dimodifikasi sebagaimana yang telah diuraikan pada bab sebelumnya.

Tahap pertama dari model 4-D yang diadopsi dari Thiagarajan adalah tahap pendefinisian. Tahap ini dilakukan peneliti pada bulan Nopember 2015. Tujuan dari tahap ini adalah untuk menetapkan dan mendefinisikan proses serta tahapan dalam pembuatan buku ajar Bahasa Indonesia dengan model CIRC. Fokus dari tahap ini adalah analisis akar masalah, analisis siswa, analisis konsep, analisis tugas dan analisis tujuan pembelajaran. 
Tahap perancangan bertujuan untuk mendapatkan draf awal atau draf I buku ajar yang dikembangkan. Draf I buku ajar dilengkapi daftar isi, panduan penggunaan buku, glosarium, indeks dan daftar pustaka. Masing-masing bagian mempunyai keterkaitan peran dalam menyampaikan isi dari draf I buku ajar. Draf I merupakan hasil dari penyuntingan tulisan buku ajar yang disusun agar menjadi buku pelajaran siswa yang sesuai dengan BSNP. Untuk itu, draf I divalidasi oleh validator yang ahli di bidangnya supaya layak digunakan oleh siswa SD kelas V. Validasi ini meliputi validasi isi atau materi, bahasa, penyajian dan kegrafikaan.

Dari hasil validasi draf I ditemukan bahwa (1) komponen kelayakan materi mendapat persentase $75 \%$ dan dikategorikan sangat layak digunakan tanpa revisi, (2) komponen kelayakan penyajian mendapat persentase $90 \%$ dan dikategorikan sangat layak digunakan tanpa revisi, (3) komponen kelayakan kebahasaan mendapat persentase $71,42 \%$ dan dikategorikan sangat layak digunakan tanpa revisi, (4) komponen kegrafikaan mendapat persentase $54,54 \%$ dan dikategorikan layak digunakan dengan sedikit revisi. Dengan demikian persentase akhir dari penilaian validator terhadap draf I buku ajar adalah $72,74 \%$ hal tersebut dapat dikatakan layak digunakan dengan sedikit revisi.

Tahap pengembangan merupakan tahap setelah perancangan buku ajar, beberapa hal yang dapat dilakukan dalam tahap pengembangan yaitu: revisi hasil validasi draf I, validasi buku teks draf II, revisi hasil validasi draf II, uji coba terbatas dan uji coba luas.

Kualitas buku ajar bahasa Indonesia dinilai berdasarkan penilaian validator dan penggunaannya di dalam kelas. Penilaian validator dilihat dari aspek materi, bahasa, penyajian dan kegrafikaan. Pada kualitas penggunaannya dinilai dari aktivitas guru dan siswa, respons guru dan siswa, serta hasil belajar siswa. Uji kelayakan buku ajar dilakukan pada uji coba terbatas dan uji coba luas.

Dari hasil perhitungan validasi draf II ditemukan bahwa (1) komponen kelayakan materi validator I mendapat persentase $90,62 \%$ dan validator II mendapatkan persentase $93,75 \%$, dikategorikan sangat layak digunakan tanpa revisi, (2) komponen kelayakan penyajian validator I mendapat persentase $92,5 \%$ dan validator II mendapatkan persentase $90 \%$, dikategorikan sangat layak digunakan tanpa revisi, (3) komponen kelayakan kebahasaan validator I mendapat persentase $100 \%$ dan validator II mendapatkan persentase $92,85 \%$, dikategorikan sangat layak digunakan tanpa revisi, (4) komponen kegrafikaan validator I mendapat persentase $86,36 \%$ dan validator II mendapatkan persentase $90,90 \%$, dikategorikan Sangat layak digunakan dengan sedikit revisi. Dengan demikian persentase akhir dari penilaian validator I terhadap draf II buku ajar adalah 93,37\% sedangkan validator II sebesar $91,87 \%$, hal tersebut dapat dikatakan sangat layak digunakan.

Setelah dilakukan analisis terhadap uji coba terbatas kemudian dilakukan uji coba luas. Buku ajar kemudian diujicobakan secara luas. Uji coba luas dilakukan pada tanggal 1 Juni 2016. Uji coba luas dilaksanakan di satu kelas yaitu kelas V di SD Hang Tuah 6 Surabaya. Pelaksanaan uji coba luas dikelas dilakukan untuk mengetahui keefektifan buku ajar yang dikembangkan. Buku ajar diujicobakan pada 25 responden, dengan rincian 24 siswa dan 1 guru. Penilaian dalam uji coba luas meliputi aktivitas guru dan siswa, respon guru dan siswa serta hasil belajar siswa.

Pada uji coba luas aktivitas guru di kelas V memperoleh persentase $89,2 \%$ dengan kriteria baik sekali. Hal ini sesuai dengan pendapat Arikunto (2006:40) aktivitas guru tersebut masuk dalam interval $81 \%-100 \%$ dengan kriteria sangat baik. Secara keseluruhan, respon guru terhadap draf III buku ajar memperoleh skor 87,5\% dengan kriteria sangat layak. Persentase aktivitas siswa adalah $91,40 \%$. Berdasarkan hasil tersebut, simpulan aktivitas siswa selama pembelajaran termasuk dalam kriteria sangat baik. Respon siswa untuk penggunaan buku ajar diperoleh hasil rata-rata sebesar $83,33 \%$ dengan kriteria sangat layak. Hasil belajar siswa untuk rata-rata kelas Hasil skor rata-rata untuk pre test yaitu 67,53 sedangkan hasil rata-rata untuk post-test 82,63 . Dari hasil rata-rata pre-test dan post-test, hasil belajar siswa mengalami peningkatan sebesar 15,1.

Untuk mengetahui ketuntasan klasikal dalam uji coba terbatas menggunakan rumus jumlah siswa yang tuntas dibagi jumlah seluruh siswa dikali 100\%. Dari rumus tersebut ketuntasan klasikal hasil pre-test yaitu 41,66\%, sedangkan ketuntasan klasikal post-test yaitu 58,33\%. Dari hasil ketuntasan klasikal pre-test dan post-test mengalami peningkatan sebesar $16,67 \%$. Berdasarkan ketuntasan minimal yang diterapkan, maka hasil post-test dinyatakan tuntas.

Buku ajar bukan hal mudah. Secara teknis yang dilakukan dalam pembuatan buku ajar yaitu menganalisis kurikulum, menganalisis sumber belajar, dan menganalisis karakter siswa. Menganalisis kurikulum tertuju pada kompetensi inti dan kompetensi dasar yang akan dikembangkan. Analisis sumber belajar yaitu dari hasil perolehan informasi dengan materi pokok yang akan dijabarkan. Analisis karakteristik siswa bertujuan untuk mengetahui kondisi dan perkembangan siswa. 
Pemilihan bacaan yang sesuai dengan materi KI dan KD serta sesuai dengan kebutuhan siswa agar siswa dapat memahami materi dan dapat berliterasi berbahasa. Aspek literasi berbahasa yang digunakan adalah literasi membaca dan menulis. Sesuai dengan pendapat Tomkins (1991:18) mengemukakan bahwa literasi merupakan kemampuan menggunkan membaca dan menulis dalam melaksanakan tugas yang bertalian dengan dunia kerja dan kehidupan di luar sekolah. Siswa dapat menyimpulkan bacaan yang terdapat dalam buku ajar yang dikembangkan.

Kegiatan pembelajaran dengan menggunakan buku ajar Bahassa Indonesia dengan model CIRC dapat membantu guru dalam proses pembelajaran di kelas. Hal tersebut terbukti bahwa persentase aktivitas guru pada uji coba terbatas pada kelas V memeroleh hasil 89,2\% dengan kriteria sangat baik sedangkan pada uji coba luas aktivitas guru di kelas $\mathrm{V}$ memeroleh persentase 92,04\% dengan kriteria sangat baik Hal ini sesuai dengan pendapat Arikunto (2006:40) aktivitas guru tersebut masuk dalam interval 81\%-100\% dengan kriteria sangat baik.

Selama proses pembelajaran berlangsung memberikan dampak positif terhadap keaktifan dan hasil belajar siswa. Keaktifan siswa terlihat pada antusias siswa terhadap pembelajaran. Hal itu terbukti dari persentase aktivitas siswa pada uji coba terbatas mendapatkan persentase sebesar $85,93 \%$ dengan kriteris sangat aktif, sedangkan aktivitas siswa pada uji coba luas memeroleh persentase sebesar $91,40 \%$ dengan kriteria sangat aktif.

Sementara itu hasil belajar siswa juga mengalami peningkatan. Peningkatan hasil belajar dilihat dari hasil pretest dan post-test pada uji coba terbatas meningkat sebesar 17,11, sedangkan peningkatan hasil belajar pre-test dan post-test pada uji coba luas meningkat sebesar 15,1. Berdasarkan penjelasan di atas, dapat disimpulkan bahwa buku ajar Bahasa Indonesia dengan model CIRC yang dikembangkan dapat meningkatkan keterampilan literasi berbahasa siswa pada siswa kelas V Sekolah Dasar.

\section{PENUTUP}

\section{Simpulan}

Simpulan yang dipaparkan ini berdasarkan hasil penelitian yang disesuaikan dengan rumusan masalah. Dari penelitian ini, maka dapat disimpulkan bahwa proses pengembangan produk melalui tiga tahapan yaitu tahap pendefinisian, perancangan, dan pengembangan. Tahap pendefinisian meliputi lima langkah pokok yang harus dilakukan yaitu analisis awal akhir, analisis karakteristik siswa, analisis konsep, analisis tugas, dan analisis tujuan pembelajaran. Tahap perancangan meliputi penulisan dan penyusunan buku ajar Bahasa Indonesia dan validasi draf I.
Tahap pengembangan meliputi revisi hasil validasi draf I, validasi buku ajar draf II, revisi hasil validasi draf II, uji coba terbatas, dan uji coba luas.

Kualitas buku ajar dinilai dari segi produk dan dari segi penggunaannya di kelas. Dari segi produk, buku ajar Bahasa Indonesia dinilai dari komponen materi, penyajian, bahasa, dan kegrafikaan. Komponen materi mendapat skor 29 dengan persentase 90,62\%. Komponen penyajian mendapat skor 37 dengan persentase $92,5 \%$. Komponen kebahasaan mendapat skor 28 dengan persentase $100 \%$. Komponen kegrafikaan mendapat skor 38 dengan persentase $86,36 \%$. Dari hasil penilaian validator diperoleh persentase rata-rata 92,37\% dengan kategori sangat layak.

Kualitas buku ajar Bahasa Indonesia dilihat dari segi penggunaan di kelas ditentukan oleh aktivitas guru, respon guru, aktivitas siswa, respon siswa, dan hasil belajar siswa. Hasil uji coba luas yaitu aktivitas guru di kelas $\mathrm{V}$ mendapat persentase 92,04\%, respon guru mendapat persentase $87,5 \%$, aktivitas siswa mendapat persentase $91,4 \%$, dan respon siswa yang menjawab iya mendapat persentase 83,33\%. Hasil belajar di kelas V dari hasil pre-test dan post-test pada uji coba luas mengalami peningkatan sebesar 15,1 .

Saran

Penelitian ini perlu ditindaklanjuti karena pengembangan buku ajar hasil penelitian belum pada tahap akhir yaitu penyebaran. Penyempurnaan buku ajar ini perlu terus dilakukan, agar tidak hanya mudah dipahami oleh siswa SD Hang Tuah 6 Surabaya saja namun juga mampu dipahami oleh seluruh siswa SD di Indonesia khususnya kelas V.

Saran bagi guru SD sebaiknya dalam menyusun materi pelajaran sebaiknya memperhatikan karakteristik dan kebutuhan siswa serta mengajarkan tata cara penulisan dan ejaan yang benar. Saran bagi siswa lebih sering mencari referensi materi dan membaca buku-buku yang lain agar wawasan dan daya menalar menjadi luas.

Sementara kepada peneliti lain buku ajar, agar dalam penyusunan buku ajar, hendaknya terlebih dahuluu menganalisis kurikulum sesuai dengan $\mathrm{KI}$ dan $\mathrm{KD}$, memperhatikan karakteristik siswa, menganalisis materi yang berkaitan dengan kehidupan sehari-hari, dan dalam menyusun buku sesuaikan dengan standar BSNP.

\section{DAFTAR PUSTAKA}

Ahmadi Abu dan Widodo Supriyono. 2010. Psikologi Belajar. Jakarta: Rineka Cipta

Amri Sofan. 2013. Pengembangan \& Model Pembelajaran dalam Kurikulum 2013. Jakarta: PT Prestasi Pustakarya 
Arikunto Suharsimi. 2010. Prosedur Penelitian Suatu Pendekatan Praktik. Jakarta: PT Rineka Cipta

Barwati Oktofiana. 2015. Literasi dalam Teks Eksplanasi Siswa di SMPN 17 Kendari. Tesis. surabaya:unesa

Ediger, Marlow. 2002. Children's Literature in the Language Arts. Philippines: Opinion Papers

Greene dan Petty. 1981. Developing Language Skill in The Elementary Schools, Boston: Alyn and Bacon Inc.,

Kartono. Kartini. (1996). Psikologi Umum. Bandung: Mandar Maju

Koraf, Ofra dan Shamir, Adina. 2012. Direct and Indirect Teaching: Using E-Books For Supporting Vocabulary, Word Reading, and Story Comprehension For Young Children. Israel: Bar-llan University

Magner, Thomas F. 1995. The Folklore of Language Teaching. Pennsylvania State: Modern Language Association

Lie Anita. 2008. Cooperative Learning. Mempraktikkan Cooperative Learning di Riang-ruang Kelas. Jakarta: Pusat Bahasa

Muslich, Mansur. 2010. Texsbook Writing: dasar-dasar Pemahaman, Penulisan dan Pemakaian Buku Teks. Jogjakarta: Ar-ruzz Media

Nation, 1 S P. 2010. Learing Vocabulary in Another Language. Cambridge: Learning Vocabulary in Another Language

Nisbet, Deanna L. 2010. Vocabulary Instruction for Second Language Readers. Virgina: Regent University

Nurgiyantoro, Burhan. 2001. Penilaian dalam Pengajaran Bahasa dan Sastra. Yogyakarta: BPFE Yogyakarta.

Nurgiyantoro, Burhan. 2010. Penilaian Pembelajaran Bahasa Berbasis Kompetensi. Yogyakarta: BPFEYogyakarta

Riduwan. (2010) Dasar-dasar Statistika. Bandung: ALFABETA

Riduwan. 2005. Skala Pengukuran Variabel-variabel Penelitian. Bandung: Alfabeta

Rofi'uddin, Ahmad dan Darmiyati Zuchdi. 1998. Pendidikan Bahasa dan Sastra Indonesia di Kelas Tinggi. Jakarta: Depdikbud

Slavin Robert E. 2011. Psikologi Pendidikan Teori dan Praktik. Jakarta:PT. Indeks

Slavin Robert E. 2005. Cooperative Learining Theoru, research and practice. London: Allymand Bacon

Sugiyono. 2008. Evaluasi Pembelajaran Di SD. Jakarta: Depdiknas

Sugiyono. 2013. Metode Penelitian Pendidikan Pendekatan Kuantitatif, Kualitatif, dan R\&D. Bandung: Alfabeta
Tompkins, Gail E. Dan Kenneth Hoskisson. 1991. Language Arts: Content and Teaching Strategies. New York: Max Well Macmillan Internationaal Publishing Group.

Thiagarajan, Sammel D, dan Semmel M (1974). Intructional Development for Training Teacher of Exeptional Children. Minnesota: Grant

Trianto. 2007. Model Pembelajaran Terpadu dalam Teori dan Praktek. Jakarta: Prestasi Pustaka Publisher

http://www.theguardian.com/news/datablog/2015/dec/23/pi sa-results-country-best-reading-maths-science

Walpole, Ronald. 1993. Pengantar Statistik. Jakarta: PT Gramedia Pustaka Utama.

Zuchdi, Darmiyati. 2007. Strategi Meningkatkan Kemampuan Membaca: Peningkatan Komprehensi. Yogyakarta: UNY Press. 